Acta arachnol., 42 (2): 129-133, December 23, 1993

\title{
Records of Lathys sexoculata (Araneae: Dictynidae) from Japan, with a Description of the Male
}

\author{
Hirotsugu $\mathrm{ONO}^{1)}$ and Kiyoto OGATA ${ }^{2)}$ \\ 小野展嗣 ${ }^{1)}$ ・緒方清人 ${ }^{2)}$ ：日本におけるムツメカレハグモの記録 \\ およびその雄の記載
}

\begin{abstract}
Lathys sexoculata Seo et SoHn, 1984, Araneae, Dictynidae, is recorded from Aichi, Tottori, and Hiroshima Prefectures, southwestern Japan. Its male is described for the first time and the palpal organ is illustrated. The dictynid spider recorded as Lathys punctosparsa from Okayama Prefecture by NisHIKAWA and KaWANAKA (1973) was considered to be the same as L. sexoculata.
\end{abstract}

The six-eyed dictynid, Lathys sexoculata, was described by SEO and SoHN (1984) from Mt. Keum, Namhae-gun, Gyeongsangnam-do, southern Korea, based on a single female specimen. The spider seems rare in Korea because it has never been recorded again in the country. The second record of the spider was made in Kanagawa Prefecture, central Japan, with a female specimen collected by Mr. T. Suwa (ONo, 1991), and the male of the species was left unknown.

During a faunistical study of spiders in Aichi Prefecture, southwestern Honshu, Japan, the junior author recognized that the spiders of Lathys sexoculata frequently occur under dead leaves on the ground in various parts of the area. He obtained also some male specimens. On the other hand, some specimens of the same species including males collected from Hiroshima Prefecture were provided for the senior author's study by Mr. Y. IHARA. The spider was also collected from Tottori Prefecture (personal communication by IHARA). Other than these records, the authors considered the female spider from Hiruzen, Okayama Prefecture, recorded and illustrated by NishiKaWA and KaWANAKA (1973) as Lathys punctosparsa (?) to be the same species as L. sexoculata.

In the present paper, the authors report these new records and describe the male of the dictynid spider for the first time with illustrations of the palpal organ.

The authors wish to express their sincere thanks to Mr. Yoh IHARA, Hiroshima, for offering interesting specimens and kind advice.

The specimens of the spider used in this paper are deposited in the collection of

1) Department of Zoology, National Science Museum, Tokyo, 3-23-1, Hyakunin-chô, Shinjuku-ku, Tokyo, 169 Japan

国立科学博物館動物研究部 $=169$ 東京都新宿区百人町 3-23-1

2) 10-6, Higashiyama, Yamayashiki-chô, Chiryû-shi, Aichi, 472 Japan

T472 愛知県知立市山屋敷町東山 10-6

Accepted November 8, 1993 
the National Science Museum (Nat. Hist.), Tokyo (NSMT).

\section{Lathys sex culata SEO et SOHN, 1984}

(Figs. 1-4)

Lathys punctosparsa (?): NishiKaWA \& KaWANAKA, 1973, p. 224, fig. 9 (nec L. punctosparsa OI, 1957).

Lathys sexoculata SEo et SoHn, 1984, p. 114, figs. 1-5 (holotype: female, Mt. Keum, Namhae-gun, Gyeongsangnam-do, Korea, 3-VIII-1983, Bo Keun SEo leg., deposited in the collection of the Department of Biology, College of Science and Engineering, Keimyung University, Korea, not examined). —- KIM, 1991, p. 276. — ONO, 1991, p. 37, figs. 1-3.

Specimens examined. Japan: Aichi Pref. (K. Ogata leg.): Toyota-shi, Sakauéchô, 1-V-1988, 1우, 3-X-1990, 7우; Toyota-shi, Kanpachi-chô, 2-IX-1990, 1우, 1-V-1991, 1우 ; Okazaki-shi, Fujikawa-chô, 26-XI-1991, 1요, 15-I-1992, 1우; Okazaki-shi, Ôgai-chô, 7-VI-1992, 1우; Seto-shi, Sôsaku-chô, 14-V-1991, 20 우 50'; Kitashitara-gun, Inabu-chô, Kuroda, 12-VI-1993, 3우 40'; Minamishitara-gun, Hôrai-chô, 29-VI-1991, 7우. Hiroshima Pref. (Y. IHARA leg.): Hatsukaichi-shi, Nishiushirobata, 19-V-1991, 2우 207, 10-V-1992, 20․

Other records in Japan. Tottori Pref. (N. Tsurusaki leg.): Tottori-shi, 22-XI, 30-XI, 6-XII-1991, some juvenile specimens (IHARA, personal communication). Okayama Pref.: NishiKawa \& KawanaKa (1973).

Description of male (based on $10^{7}$ from Sôsaku-chô, Seto-shi). Measurement. Body length $2.00 \mathrm{~mm}$ (variation: $1.85-2.00 \mathrm{~mm}$ ); prosoma length $0.93 \mathrm{~mm}$, width
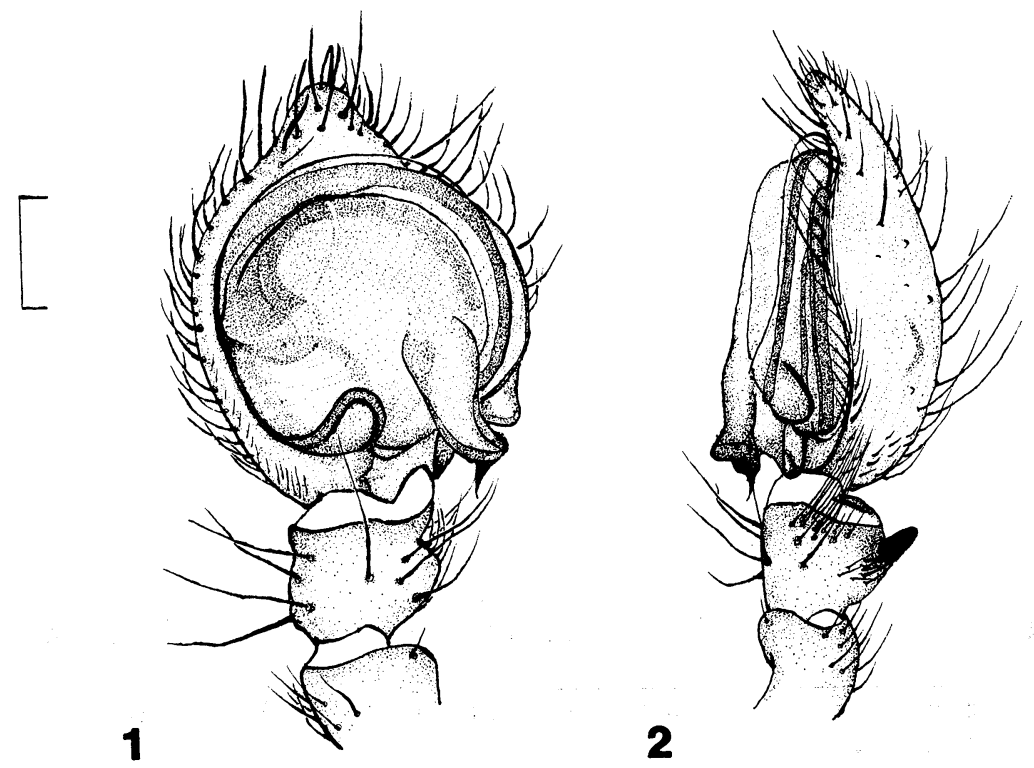

Figs. 1-2. Male palp of Lathys sexoculata SEO et SoHN, 1984, based on the Japanese specimen. - 1, Ventral view; 2, retrolateral view. (Scale: $0.1 \mathrm{~mm}$.) [K. OGATA del.] 

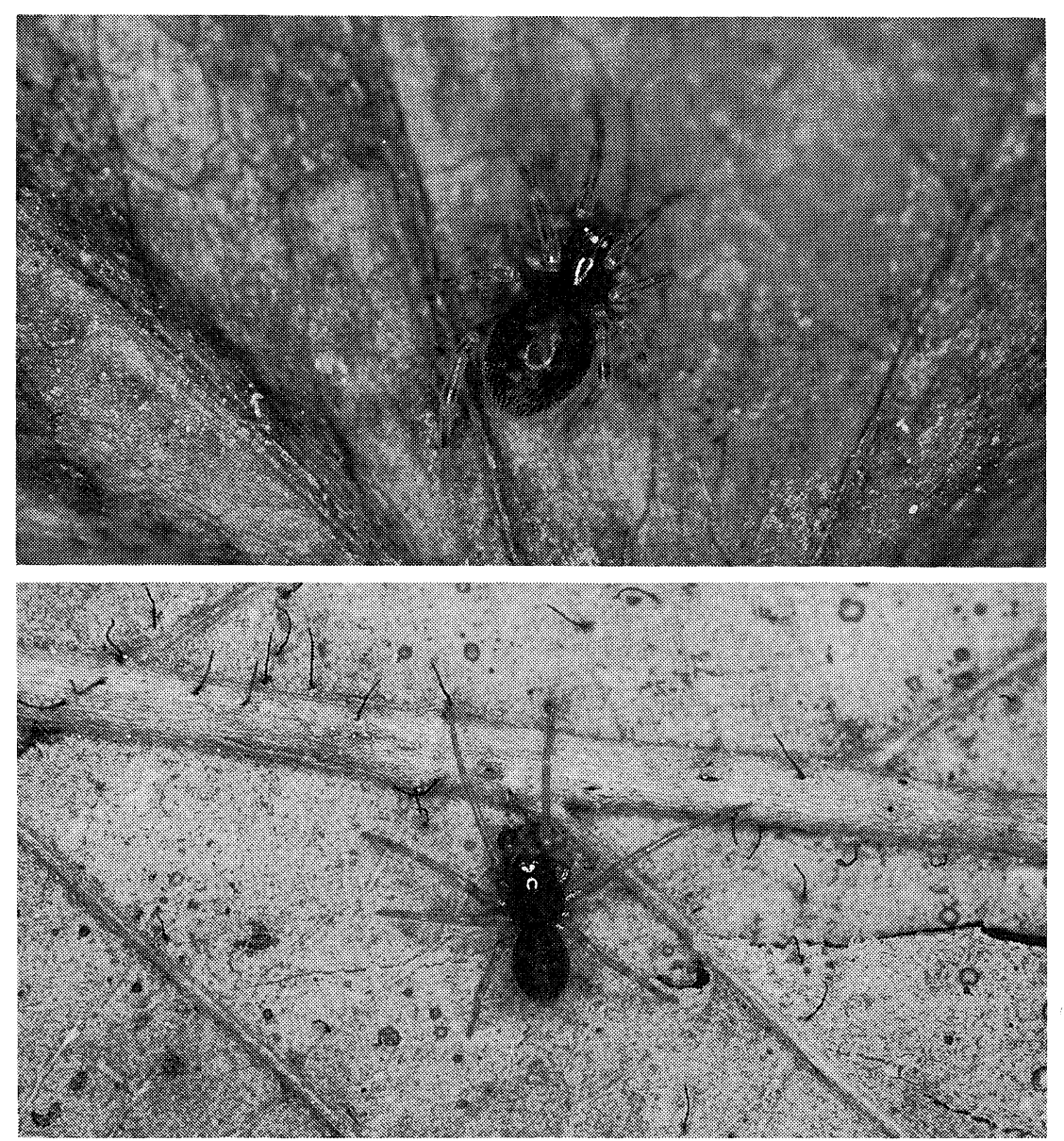

Fig. 3. Lathys sexoculata Seo et SoHn, 1984, female (upper) and male (lower). [Photo: K. OGATA.]

$0.78 \mathrm{~mm}$; opisthosoma length $1.00 \mathrm{~mm}$, width $0.75 \mathrm{~mm}$; lengths of legs [total length $($ femur + patella + tibia + metatarsus + tarsus $)]:$ I $3.46 \mathrm{~mm}(0.98+0.32+0.93+0.78+$ $0.45)$, II $2.55 \mathrm{~mm}(0.75+0.28+0.59+0.56+0.37)$, III $1.97 \mathrm{~mm}(0.59+0.25+0.40+$ $0.45+0.28)$, IV $2.35 \mathrm{~mm}(0.72+0.26+0.54+0.53+0.30)$.

Prosoma with several setae easily removed on the cephalic part, radial lines and black marking at the middle present, but furrows not distinct. Eyes similar in size, posterior lateral one the largest, anterior median one absent; posterior eye row procurved; ratio of distance between posterior median eyes to that between posterior median eye and posterior lateral eye 1.25 . Chelicera relatively long, dorsally with a long seta; promargin of fang furrow with 4 teeth, retromargin with 5 teeth; labium slightly wider than long (length/width 0.88). Sternum longer than wide (length/ width 1.10), the posterior end extending between coxae IV. Leg formula, I, II, IV, III; femora I-IV with one dorsal spine, respectively; tibiae and metatarsi I-IV with 


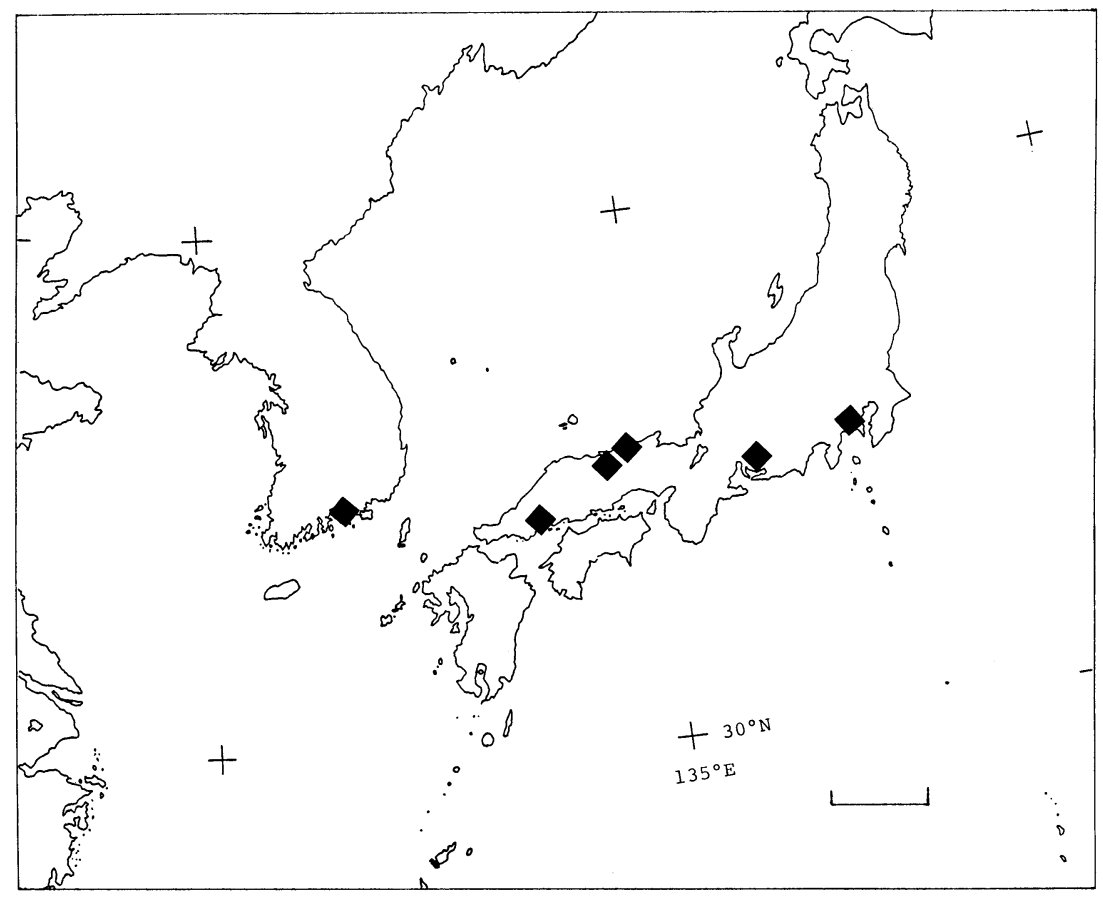

Fig. 4. Distribution of Lathys sexoculata SEO et SoHN, 1984. (Scale: 200 km.)

some weak spines on pro- and retrolateral and ventral sides.

Male palp (Figs. 1-2). Tibial apophysis uncinated, relatively short and situated in the dorsal side; bulb discoid, tegulum wide with a digitiform apophysis distally branched.

Coloration and markings. Prosoma yellowish brown with black radial lines; chelicerae, maxillae, labium and sternum light yellowish brown, legs dusky yellow, tibiae and metatarsi I-IV distally blackish. Opisthosoma dark beige with white spots as in female (Fig. 3; ONO, 1991, fig. 3).

Range (Fig. 4). Japan (Honshu), Korea.

Remarks. Contrary to the presumption by ONo (1991) on the relationship between the present species and the other six-eyed species of Japan, Lathys punctosparsa OI, 1957, in the female, there is a high probability that Lathys sexoculata stands in fact not so close to the latter on the basis of an examination of the male palpal organ (Figs. 1-2; Oi, 1961, figs. 1-2).

従来, 韓国慶尚南道南海郡および日本の神奈川県の 2 力所でしか記録がなかったムッメ カレハグモ (Lathys sexoculata SeO et SOHN, 1984) を愛知, 鳥取, 広島の各県から記録し た。また今まで未知だった雄をはじめて記載し，触肢を図示した。また，西川・川中 
(1973) により岡山県からナシジカレハグモ（?) として記録されたクモは本種と同種と推測 した。

\section{References}

KIM, J. P., 1991. A check list of Korean spiders. Korean Arachnol., 6: 275-291.

Nishikawa, Y., \& Y. Kawanaka, 1973. Spiders of the Hiruzen area, Okayama Pref. In Fauna and Flora of Hiruzen, pp. 207-243. Otemon Gakuin Univ. Biol. Club, Osaka. (In Japanese.)

OI, R., 1957. On some spiders (including a new species) from Buttuji. Acta arachnol., 14: 45-50. (In Japanese with English description.)

1961. A supplementary note on Lathys (Scotolathys) puntosparsa Or. Ibid., 17: 33.

Ono, H., 1991. Lathys sexoculata Seo et SoHn (Araneae: Dictynidae) new to the Japanese fauna. Atypus, (98/99): 37-39. (In Japanese.)

Seo, B.-K., \& S.-R. SohN, 1984. The spider fauna and three valuable species of Namhae-gun, Gyeongsangnam-do, Korea. J. Inst. Nat. Sci., Keimyung Univ., Daegu, 3: 113-120. 